\section{Science Programs in Kansas}

Groundwater and Streamflow Information Program-The

U.S. Geological Survey (USGS) helps fund and operates real-time groundwater monitoring at 14 locations and streamflow monitoring at 216 locations in Kansas to provide information for water supplies, flooding, and drought throughout Kansas.

National Water Quality Program — The USGS assesses the status and trends in water-quality throughout the State, including the Kansas River, Johnson County streams, the Republican River, Smoky Hill River, and Milford, Perry, and Cheney Reservoirs.

Sediment Transport-USGS sediment transport studies are used to assess and project the storage remaining in Kansas reservoirs and to characterize the potential of management practices to extend reservoir functions. The USGS currently (2022) is studying sediment transport up and downstream from John Redmond and Tuttle Creek reservoirs.

Harmful Algal Blooms-The Kansas Water Science Center is the home of national-scale research designed to improve the understanding of factors that cause harmful algal blooms (HABs) and their associated risks to human and environmental health. Within Kansas, active study of the causes, effects, and transport of HABs are underway in the Kansas River, in Milford and Perry Lakes, and in Cheney Reservoir. These studies are also being used to provide ground-to-space verification of satellite imagery through the Cyanobacteria Assessment Network (Cyan). This network is designed to create an early warning system to detect potentially toxic HABs nationwide.

\section{Water-Quantity and Water-Quality Effects of Artificial Groundwater}

Recharge-The USGS continuously monitors streamflow and water-quality in the Little Arkansas River basin to assess the effects of the Equus Beds Aquifer Storage and Recovery Project near Wichita, Kansas, on aquifer water-quality.

Integrated Water Availability Assessments-The USGS is characterizing surface water and groundwater availability and quality on the Prairie Band Potawatomi Nation Reservation for municipal water supply and assessing the impact of agricultural best management practices on streamflow and water quality in the headwaters of Soldier Creek.

Environmental Health Toxic Substances Hydrology Program-The program focuses on national occurrence, effects, and movement of environmental pesticides, antibiotics, algal toxins, and taste-and-odor compounds.

State Water Resources Research Institute Program-The USGS funds the Kansas Water Resources Research Institute to further research and education through Kansas universities.

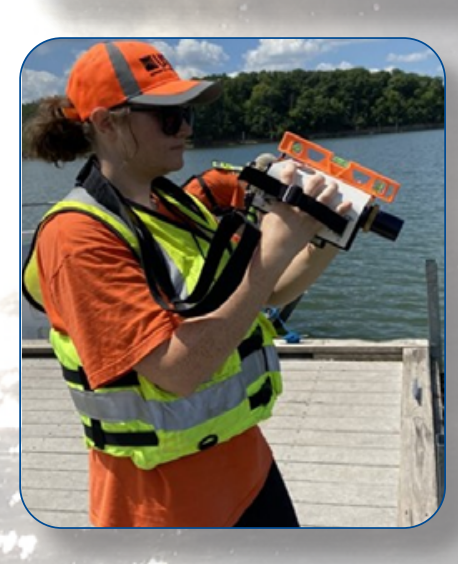

Collecting hyperspectral images, at Hillsdale Lake for ground to space verification of the Cyanobacteria Assessment Network (CyAN). The intention is to create an early warning system to detect potentially toxic harmful algal blooms (HABs).

CyAN web page: https://www.epa.gov/ water-research/cyanobacteriaassessment-network-cyan CyAN application: https://www.epa.gov/ water-research/cyanobacteria-assessment-network-application-cyan-app

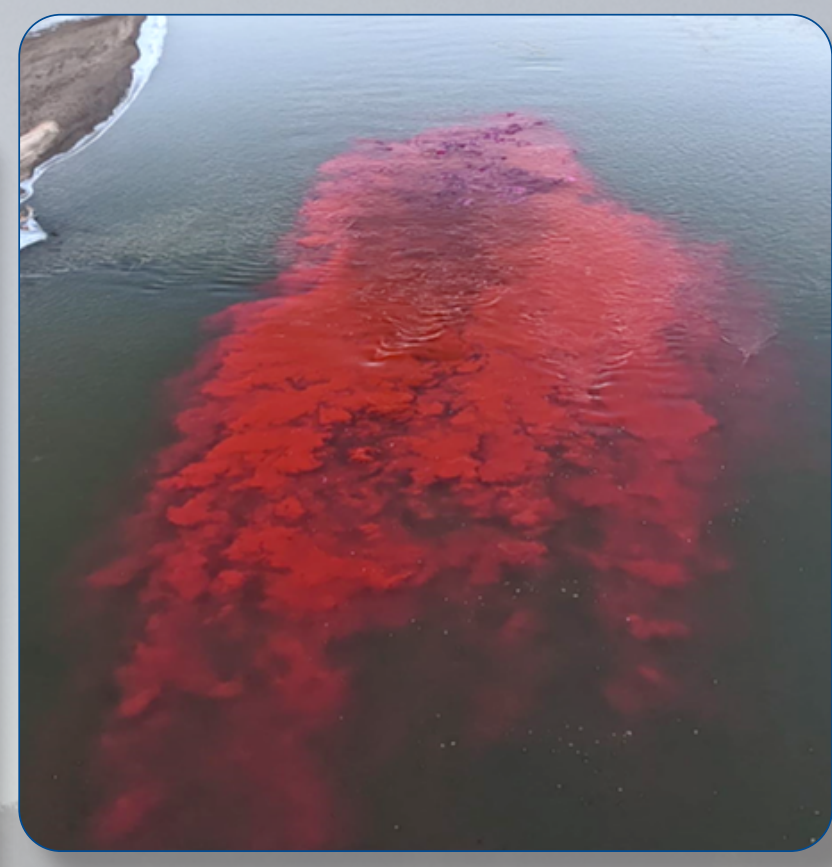

Dye tracer experiments conducted at low, medium and higher flows in the Kansas River will help provide a better understanding of how quickly water flows downstream.

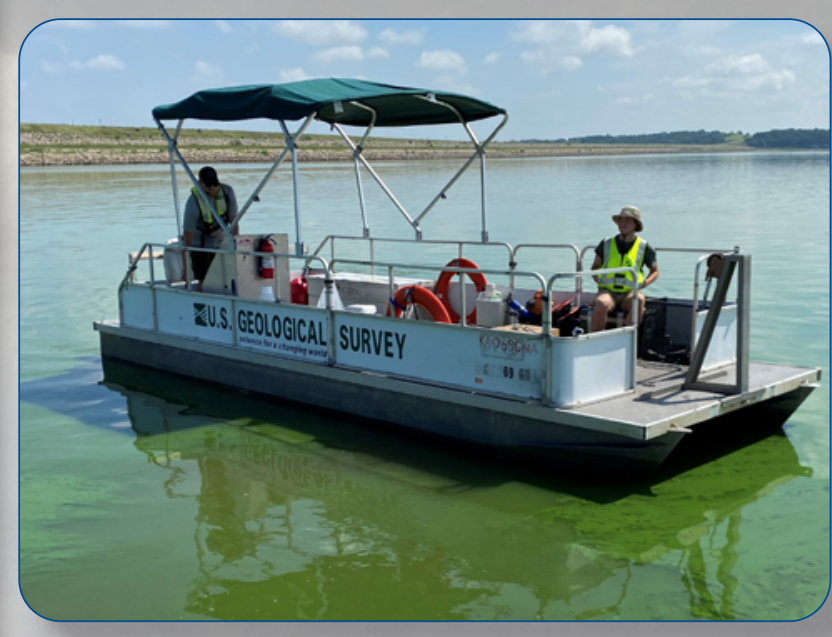

\section{Collecting water-quality samples within an algal bloom} in Milford Lake.

The USGS is a non-regulatory Earth science agency within the Department of the Interior, founded in 1879, that provides impartial scientific information to describe and understand the health of our ecosystems and environment; minimize loss of life and property from natural disasters; manage water, biological, energy, and mineral resources; and enhance and protect our quality of life. The USGS also partners with Federal, State, tribal, and local agencies to deliver long-term data in real-time and interpretive reports describing what those data mean to the public and resource management agencies. 




EXPLANATION

\begin{abstract}
(1) Congressional $\Delta$ Streamgage $\Delta$ Water quality $\bigcirc$ Groundwater level Groundwater quality district monitoring site monitoring site monitoring site
\end{abstract}

In 2022, the U.S. Geological Survey operated 216 streamgages, 14 groundwater sites, and 22 water-quality sites.

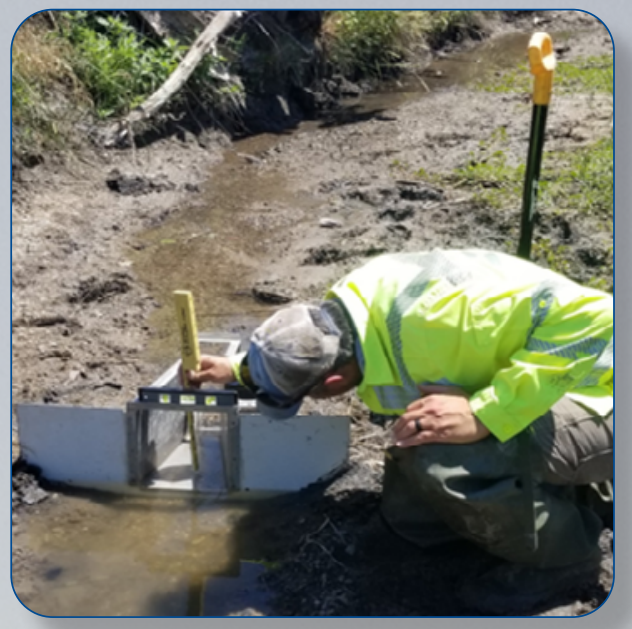

Measuring discharge at low flow using the flume method on the Smoky Hill River downstream of Schoenchen, KS.

\section{Examples of USGS Kansas Water Science Center Projects in Congressional Districts}

\section{District 1}

- Water-quality conditions in Cheney Reservoir and watershed

- Groundwater-level changes and quality in the High Plains Aquifer

- Kansas River water-quality study

- Kansas River time-of-travel study

- Ground to space verification for remote sensing of HABs

- Monitoring water quality and sediment in the Republican River

- HABs in Perry Lake and Cheney Reservoir

- Monitoring water quality and sediment below Tuttle reservoir

- Sediment sampling upstream from U.S. Army Corps of Engineers reservoirs

- Surface water and groundwater availability and quality on the Prairie Band Potawatomi Nation Reservation

- Agricultural best management practices effects on streamflow and water quality in the headwaters of Soldier Creek

\section{District 2}

- HABs in Milford Lake

- Kansas River water-quality study

- Kansas River time-of-travel study

- Ground to space verification for remote sensing of HABs

- Water-quality monitoring in the Kansas River at DeSoto, Kans.

- Monitoring sediment transport to John Redmond Reservoir and Neosho River watershed

- Sediment sampling upstream from U.S. Army Corps of Engineers and Bureau of Reclamation reservoirs

- Streambed-sediment sampling in Cherokee County Superfund site (part of the Tri-State Mining District)

\section{District 3}

- Kansas River water-quality study

- Kansas River time-of-travel study
- Ground to space verification for remote sensing of HABs

- Water-quality monitoring in Johnson County, Kans., streams

- Water-quality monitoring in the Kansas River near Lake Quivira, Kans.

\section{District 4}

- Water-quality and water-quantity effects of Equus Beds artificial groundwater recharge project

- Water-quality monitoring in the Little Arkansas River

- Assessment of per- and polyfluoroalkyl substances (PFAS) in surface water around McConnell Air Force Base

\section{Statewide}

- Streamgaging

- Streamflow statistics

- Environmental health science

- Institute funding to universities

\section{Who Cooperatively Funds USGS Science in Kansas?}

USGS Environmental Health Toxic Substances Hydrology Program, Groundwater and Streamflow Information Program, National Water Quality Program, Water Availability and Use Science Program; NASA (Goddard Space Flight Center); Centers for Disease Control; U.S. Air Force; Bureau of Reclamation; U.S. Environmental Protection Agency; U.S. Fish and Wildlife Service; The Conservation Fund; University of Maryland; Federal Emergency Management Agency (Region VII); Kansas Department of Agriculture (Division of Water Resources); Kansas Department of Health and Environment; Kansas Department of Transportation; Kansas Department of Wildlife and Parks; Kansas Geological Survey; Kansas State University; Kansas Water Office; Prairie Band of Potawatomi Nation; Arkansas River Compact Administration; Cities of Augusta, Hays, Hutchinson, Lawrence, Leavenworth, Manhattan, Ottawa, Olathe, Russell, Topeka, and Wichita; Douglas County Emergency Management; Johnson County Department of Public Works; University of Kansas Athletics; Kansas River Water Assurance District; Leavenworth County; Lower Platte South Natural Resources District; Pawnee Watershed Joint District; Shawnee County; Southwest Kansas Groundwater Management District GMD3; The Nature Conservancy; Unified Government of Wyandotte County; U.S. Army Corps of Engineers (Kansas City District and Tulsa District); Evergy; and WaterOne.

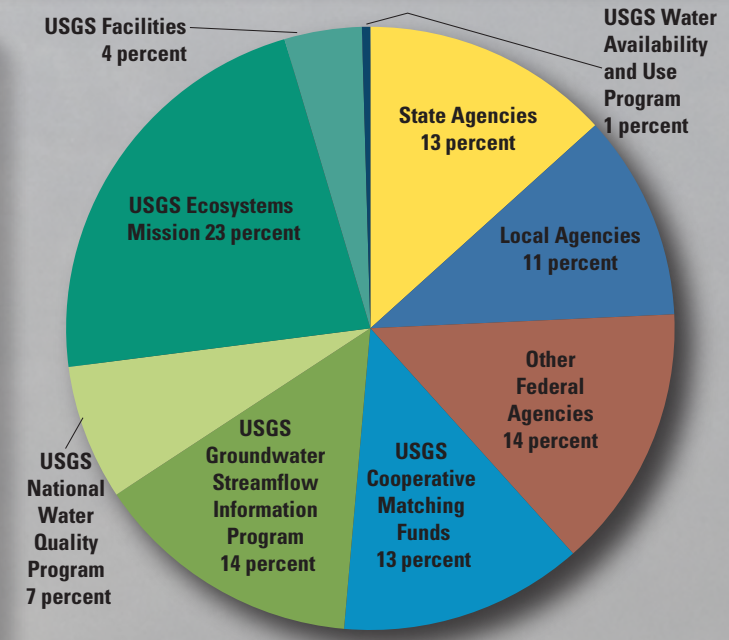

Fiscal year 2022 total funding was $\$ 9.4$ million. USGS funding was $\$ 5.8$ million (62 percent). 